\title{
SWEDISH STUDENT-TEACHERS IN DIGITAL ACTIVITIES: DIGITAL COMPETENCE THROUGH DEVELOPMENT-ORIENTED THESIS PROJECTS
}

\author{
Peter Karlsudd
}

Department of Pedagogy and Learning, Linnaeus University, Kalmar, Sweden

\begin{abstract}
This article defines attempts using development-oriented thesis projects to increase teachers' and pupils' digital capability. To offer a more practice-oriented focus in the teacher education, the elementary school student-teachers were stimulated to participate in thesis projects with the purpose of developing the school events. Thirteen of the development-oriented thesis projects carried out during 2015-2018 involved testing the student-teacher's ability to study and formulate the competence needs regarding digital learning at the practicum-school, as well as the results of carrying out activities for increasing the digital competence. The investigation is based on a review of completed thesis projects, process journals, and presentations and discussions in subsequent reports. An initial analysis of the thirteen development projects reveals two clear goal directions. One focus is on traditional knowledge goals and the other on more social goals. The outcomes clearly show that development-oriented thesis projects can be an effective way to increase the digital skills of teachers and pupils. Projects with distinct goals for collaboration and shared learning have reached further goal attainment than the projects focused more on discrete instruction and learning. When digital tools were used as a means to work with another area, for example, physical activity or democracy issues, the developed competence in digital skills became more pronounced and lasting. Digital competence is an important development area for school activities, and this study shows that development-oriented thesis projects can be an effective means toward a successful project.
\end{abstract}

\section{KEYWORDS}

Development-oriented, Digital tools, Teacher education, Teacher training, Thesis projects

\section{INTRODUCTION}

Computers were introduced into Swedish schools on a trial basis during the 1970s, and their big breakthrough came in 1994 when the Swedish Knowledge Foundation (KK-stiftelsen) was established. One of the tasks of the foundation is to support school use of ICT (information and communication technology) and since then there has been widespread, resource-intensive inservice training conducted on several occasions with varying results [1,2]. The effects on education have been greatest in projects where teachers were compensated for their invested time and where the importance of the training was jointly supported by the municipality and school board [3]. After a number of major national projects, it was found that the main use of digital resources in instruction was ICT as an information source, since the educational programs did not maintain the quality expected $[1,2,3,4]$.

At the majority of schools in Sweden today, there is good access to computers and teachers have relatively high competence regarding digital resources [5]. Nevertheless, many Swedish teachers, in comparison with teachers in other European countries, choose to use ICT to a rather limited extent [6]. One reason for this may be that the complexity of schooling increases $[7,8]$ and the use of digital equipment places new demands and approaches toward technology [9]. Another reason DOI: 10.5121/ijcsit.2019.11301 
is likely the teacher's critical and autonomous attitude, where new technology and new demands can be perceived as threatening to the individual teacher's possibility of organizing and carrying out his or her work [10,11]. The need of skills development is still considered to be very important, with the government remarking in new directives that:

"--- the Swedish school system shall be leading in using digitalization in the best way for obtaining high digital competence among children and pupils and for promoting knowledge development and equivalent education" [12, p. 4].

Based on this statement, it may be interesting to find new, more successful ways to increase the digital skills in school classrooms.

\section{Previous Research}

Studies show that pupils in elementary school believe they do not have enough skills and competence, and therefore they want to increase their capability [13,4]. Teachers' knowledge, own interests and attitudes in this area are crucial for the pupils' opportunities to develop digital skills. Digital competence refers to "the extent to which one is familiar with digital tools and services and has the ability to participate in digital development and its impact on one's life" [14, p. 16]. Investing in teacher training in order to increase the use of ICT in school activities is a success factor supported by research. Results from previous studies show that teachers' skills within ICT increase motivation and thus also the willingness to work with digital tools among teachers as well as pupils $[15,16,17]$. Other research shows that cooperation with colleagues is particularly important in in-service training with respect to teachers' digital competence [18].

Studies $[19,20,21]$ show that teachers may feel uncomfortable with using digital tools in their teaching. Teachers often consider themselves lacking in the right skills to be able manage ICTrelated activities with pupils. There are several different types of technology and digital equipment in school that teachers are expected to master, and there is often a lack of IT-support to help them find tools suitable for their pedagogical and didactic approach. Many times, specific competence is required of the user for results to be satisfactory. In recent decades digital equipment has increased in schools. Laptops and surf tablets are clearly more common in today's classrooms than they were just ten years ago. At the same time, teachers have difficulty acquiring skills development whether they are at a small or a large school (ibid).

ICT has been overly used based on the terms of the technology and not based on the teachers' and pupils' needs. What matters is whether working with digital tools leads to motivation in schoolwork and not the actual use itself[22]. Pupils see digital tools more as a means of instruction, than as a motivation factor where the use offers varying and attractive presentations (a.a.). If the right IT-didactic method is used, there can be a more profound change in the instruction [23].

There is a connection between competence development and teachers' attitudes towards ICT. If a teacher receives skills training in this area, this helps the teacher become more positive toward the use of digital tools [4]. The main difference in how teachers use media in their instruction does not depend on the generation of the teacher, but rather on the teacher's own interest in media. Although many of the younger generation teachers use digital media more than the older generation teachers, there are no direct differences in their media proficiency [16].

Unfortunately, the in-service training efforts directed towards teachers do not always have the desired effects. The lack of success is mainly due to four reasons. Poor conditions is the first, which is the lack of time and opportunity to develop their work on their own and together with 
colleagues. The second is the absence of practical change. In-service training opportunities can be interesting and worthwhile, but not lead to any long-term change in the instructional practice. The third reason is that there is a difference between the needs and the skills development interventions. The training does not lead to the competence desired. The fourth and last is questioning the utility, where teachers weigh whether their in-service training is going to benefit the pupils in the end [21].

Another major problem that becomes apparent in nearly all investigations is the lack of a pedagogical vision and a comprehensive strategy for the use of ICT in schools. Often the technology is brought in without clear goals for how it will be used in instruction. An example of this is the massive investment in interactive whiteboards in Swedish schools [4]. At many schools, school administrators focus on other issues, and unilateral efforts in other skill areas have contributed to a poor impact. Schools with clear goals and a well-founded ICT-strategy are more motivated to move forward with the work (ibid). In order to benefit noticeably from strong digital capital, educators need in-service training that inspires and motivates them to make digital resources a natural part of their teaching. Competence development must be ongoing for successful implementation and integration of ICT [24].

There are a number of obstacles that make people oppose change. These can be divided into practical, psychological, value and power barriers [10]. If a radical change is to take place, these barriers must be crossed. Practical obstacles can be finances, accessibility, opportunity for education, lack of time, etc. A psychological barrier may be that the professional person feels threatened in his or her role; perhaps there is the fear that the pupils might know more. Value barriers may be when the values accompanying the technology are not in line with the professional person's values. When a power barrier occurs, there is a challenge to the whole professional role.

A few schools still lie at the forefront in terms of digital skills, but for the majority of schools, training interventions and investment in new equipment have tapered off [25]. The reason for the differences is primarily practical and is basically about economic priorities. This may mean that digital gaps are created between schools in terms of knowledge and access to digital equipment, which becomes a problem regarding the pupil's right to equivalent education [26]. The increased decentralization and lack of national guidelines are considered to be the main reasons for the differences arising among different schools. Therefore, in October 2017, the Swedish government decided on a new national strategy for digital learning throughout the education system, from preschool to adult education. The overall goal of the national strategy is to provide pupils with the conditions for developing digital competence [12]. Research results concerning implementing ICT in schools, make it clear that this is partly about an attitude to be willing to change one's teaching with digital tools, but also about a willingness to change one's entire teaching. One's approach and desire toward using digital tools is strongly influenced by a teacher's competence in the area $[15,17]$. Teachers believe they need more experience and competence in how to use digital tools comprehensively and effectively in school activities [22]. Starting from individual teachers' knowledge view and attitude, increases the chances for successful use of digital tools in the classroom / successful competence training in the use of digital tools [27]. In regards to prospective teachers' acceptance of digital tools in instruction, the results are somewhat fragmented. In a study [28] with 466 student-teachers who represented four different types of teacher education programs, results show that the student-teachers can be divided into three groups. A small group of student-teachers have a number of reservations about using ICT in school, and many in this group are clearly negative. Another group, slightly larger, has a more vague and ambivalent attitude. The third group, which makes up more than one-third of the respondents, has a clearly positive attitude toward digital tools in instruction. 
A relatively untapped resource for increasing ICT-competence in school activities is the collaboration with student-teachers, who complete a training placement during a significant portion of their education. In addition to this, the final requirement of the teacher education program, the thesis project, is often closely linked to empirical data collection at the students' practicum-schools. Here is an opportunity to conduct projects where increasing the capability with digital resources is the focus for development-oriented studies. Offering student-teachers, who are interested and positive toward developing the practicum-school's digital competence, the assignment of carrying out a development-oriented project can then be a good idea.

It can then be a good idea to offer the assignment of carrying out a development-oriented project to student teachers who are interested and positive toward developing the practicum-school's digital competence.

\section{THESIS PROJECTS IN THE TEACHER EDUCATION PROGRAM}

In the Swedish teacher education program, there are four different professional qualifications, namely, preschool teacher, elementary teacher, subject teacher and vocational teacher. The educational content depends on the school type where the qualified teacher will teach. The framework is set by the curriculum and syllabus, but the teacher education instructors together with the students are responsible for the content of the instruction. The teacher training programs are at least three years, and the longest education program is five and a half years. The difference in length depends on the focus of the education program.

The thesis projects produced in the Swedish teacher education program are almost exclusively written reports and seldom consist of a research project, where practical development is at the core and teachers at the practicum-schools have been involved in the work [29]. The Swedish National Agency for Higher Education has previously pointed out in evaluations that thesis projects in the new teacher education program often have a formal, academic character where scientific craftsmanship and methodological requirements are given more attention than the central problems of the teaching profession [30]. Not uncommon are arguments that the traditional, more academically-oriented project risks having little transferability to real professional practice, while the more classroom-based thesis project risks shortcomings in its documentation and scientific rigor [31,32,33]. An academic professional education should be able to fulfill the criteria for professional relevance and scientific rigor even when it is directed toward development of classroom activity [34]. The goal is to tie academia and profession closer together $[35,36]$. The development projects presented in this article build on this background.

The requirement for thesis projects to be based on scientific grounds and proven experience, is something often interpreted as one or several theories are presented in a special chapter and thereafter referred to in the analysis and discussion. It is common, but not always necessary to introduce specific theories that are usually considered "grand" and can be exemplified by representatives such as Maslow [37] and Piaget [38]. A work can also be solidly grounded on the scientific basis of methodology, pedagogical principles (ontology and epistemology) as well as on previous research rooted in presented theory that forms a reliable foundation for data analysis.

Many times, thesis projects are criticized for being weak in theory, and even if a theory is presented in a special chapter, it is not rare for a clear theoretical basis to be lacking in the rest of the work. The references to the theory that happen in the discussion are many times vague and faint. In development-oriented work, it becomes possible to clarify the theoretical basis by the author analyzing the pedagogical principles and previous research based on the theories the method builds upon, for example, the choice of developmental model. 
That student-teachers in development-oriented thesis projects focus on the currently prioritized work of increasing IT-competence among teachers and pupils, can be a way to increase professional relevance and promote development of classroom activity without the requirements for scientific rigor in thesis projects being left out. Such focus could be beneficial for the studentteachers as well as the classroom teachers and pupils [29].

\section{AIM}

The purpose of this research was dedicated to the development-oriented projects, explore the student-teachers' aptitude to investigate and express the teachers' and pupils' needs for ICT skills, and plan and conduct actions for increasing the things. The aim can be expressed in the following goal statements.

To study and analyze:

- the design and form of the development-oriented thesis project

- student-teachers' ability to carry out development-oriented projects in ICT and learning,

- obstacles and success factors in different development strategies and the activities carried out.

\section{METHOD}

In order to provide the opportunity for a more professionally-oriented focus, the elementary student-teachers were offered the choice between two alternatives for carrying out their thesis projects. The first alternative was that which dominated for many years, referred to as a traditional project. This type of project deepens primarily knowledge about traditional research. The other alternative was to plan and carry out a development project on theoretical grounds, with the intention of developing the school activity. The development-oriented project can be likened to a systematic qualitative project or an development-research project where the implementation takes place in the classroom and the leisure-time centre activities as well as being designed in collaboration with the classroom teachers. The aim with this process is to gain new knowledge, document and critically review it, and disseminate the experience to other schools [29]. With this focus, the students' own efforts to create change in the learning activities are central. The present investigation brought together development projects directed toward ICT and learning, since they were considered to be particularly important for finding effective ways of increasing the teachers' and thereby also the pupils' competence in this area.

Besides the methods that touch on systematic quality work and development research, there are several other methodologies and methods that are suitable to use in a classroom development project. Intervention studies, participatory research, study circles and entrepreneurial learning are some examples. What is common for these methods, is finding out through action what interventions aid development and the possibility of lasting change.

A fundamental requirement for a development-oriented project is that it be based on the participants' needs and be carried out in cooperation with the staff. The development area should be relevant for the education profile and the prospective professional role. In a developmentoriented work, current state analysis, needs analysis, goal formulation, methodology and procedures are central. The current state analysis and the needs analysis provide answers to the questions, What? and Why? What will be studied and developed? Why is it interesting, relevant and important? For whom, for what? It is important to identify, limit and define the development area and show the relevance of the planned interventions [ibid]. What knowledge contribution and what developmental effects does the project strive to achieve? The next step is related to How? In what way will the knowledge and development be achieved? It is important that the 
methods are related to the situation and conditions of the activity and that the project is implemented on the basis of scientifically-grounded research and development models. This investigation is based on the documentation presented in the thesis projects where academic supervision and debate assure the validity, and on the discussions written in subsequent reports.

\subsection{Selection}

Thirteen development projects with the goal of developing ICT-competence in learning activities are analysed in this study. The student-teachers who conducted the development-oriented projects come from the branch of teacher education that leads to an elementary school teacher working in a leisure-time centre. This education program comprises three years of study and provides qualification for working with children during their free time before and after school, in a curriculum-based school activity. The development projects have been carried out during 20152018, and they encompass all the development projects dealing with ICT in this education program during this period. In the majority of the development projects, the students worked in pairs under the supervision of qualified teacher educators

\subsection{Ethical considerations}

The fundamental ethical requirements for protecting respondents in research are the information requirement, the consent requirement, the confidentiality requirement and the utility requirement [39]. In this investigation these requirements were safeguarded through clear information about the project objectives and the absolute right to withdraw from participation. All schools that took part have been positive toward participating, and the development-oriented thesis projects carried out by the student-teachers have been conducted under supervision with strict observance of ethical requirements. In order not to reveal the schools, the documented projects are presented anonymously. Per the research the results of the investigation will only be used with the school and the scientific community with the desire to recover competence development in the area of ICT.

\section{Results}

It is clear that development-oriented projects are a viable way to strengthen digital competence among teachers and pupils. All projects have contributed to this finding to varying degrees. Previously, more traditional thesis projects investigated knowledge and attitudes, as well as described already implemented work methods; in contrast, the development-oriented thesis projects in addition contribute to developing the classroom activity through action.

This conducted study, comprising 13 development-oriented ICT projects, must be seen as exploratory. The summary, categorization and assessment are based upon documentation and reports submitted in the thesis projects and process journals, and the presentations following the projects. The categorization and assessment of the goal attainment of the development-oriented projects in terms of increasing competence have been completed by the head examiner. The final reports involved the teachers from the practicum-schools, which possibly strengthens the validity.

Concepts such as generalizability must be discussed with great caution, but the valuation of the experience presented is likely to be valuable for continuing with a more standardized, controlled study. In the 13 development projects described in the study, a number of methods were used in the current state analysis and the needs analysis. Examples of the most common methods are interviews with staff and pupils. Group interviews, surveys and observations are other examples of research methods used. In all cases, the goal formulations in the projects have been directed toward developing ICT-competence in the leisure-time centre, but the starting point has been 
different. In an initial, overall division of the projects, two clear goal directions can be seen. One focus is on more traditional knowledge goals and the other is on more social goals. By traditional knowledge is meant, for example, how computer programs function and how to relate to digital tools. Social goals focus on practical application of tools and programs in interaction with others. In the developmental projects reviewed, the project design can be described as either instructional or as planning and exploratory work in collaboration. These design types can appear in both goal directions, but the instructional orientation is dominated by traditional knowledge goals.

In two projects, the interventions were entirely directed toward the teachers and in three to the pupils. In eight of the projects, both teachers and pupils have been involved, but then it is not uncommon for one of the groups to receive particular attention. The table below (Table 1) presents the different project designs, goals and methodologies in the six different strategies/designs. The analysis is based on documentation and statements submitted in the thesis projects, process journals and the reports following the projects.

Table 1: Project designs, goals and methodologies in the six different strategies/designs.

\begin{tabular}{|c|c|c|c|c|}
\hline Projectdesign & Goal & Method and Procedures & $\begin{array}{c}\text { Know } \\
\text { ledge } \\
\text { goal }\end{array}$ & $\begin{array}{c}\text { Social } \\
\text { goal }\end{array}$ \\
\hline \multirow[t]{3}{*}{ Instructpupils. } & $\begin{array}{l}\text { 1. The goal of the procedures was to } \\
\text { increase the ICT-skills of the pupils and } \\
\text { thereby also increase motivation for } \\
\text { learning. }\end{array}$ & $\begin{array}{l}\text { Pupils worked with iPads } \\
\text { using learning games. }\end{array}$ & Yes & No \\
\hline & $\begin{array}{l}\text { 2. The goal was to develop both } \\
\text { technology and social skills through } \\
\text { using digital equipment. }\end{array}$ & $\begin{array}{l}\text { Through three types of } \\
\text { activities: film-making, play } \\
\text { and games, the pupils' artistic } \\
\text { capability and creativity are } \\
\text { challenged. }\end{array}$ & Yes & Yes \\
\hline & $\begin{array}{l}\text { 3. The goal of the procedures was to } \\
\text { increase the knowledge and the technical } \\
\text { handling of source criticism on the } \\
\text { Internet. To encourage pupils to make } \\
\text { intelligent searches and thereby increase } \\
\text { their confidence in information searches. }\end{array}$ & $\begin{array}{l}\text { Several short lessons where the } \\
\text { pupils got to use the Internet to } \\
\text { answer questions. Discussion } \\
\text { about search results and } \\
\text { credibility. }\end{array}$ & Yes & No \\
\hline $\begin{array}{l}\text { Instruct } \\
\text { teachers. }\end{array}$ & $\begin{array}{l}\text { 4. In an educational interventional, } \\
\text { change teachers' attitudes towards } \\
\text { working with digital tools in the leisure- } \\
\text { time center. }\end{array}$ & $\begin{array}{l}\text { Education and projects aided } \\
\text { by iMovie, Google Earth and } \\
\text { QR-codes. }\end{array}$ & Yes & No \\
\hline $\begin{array}{l}\text { Instructpupils } \\
\text { and teachers. }\end{array}$ & $\begin{array}{l}\text { 5. The goal of the procedures was to } \\
\text { increase the use of digital tools in the } \\
\text { leisure-time center through inspiring the } \\
\text { educators and pupils toward practical } \\
\text { work with digital tools. }\end{array}$ & $\begin{array}{l}\text { Establishment of a blog at two } \\
\text { leisure-time centers where the } \\
\text { pupils act as writers. } \\
\text { Collaborative learning was a } \\
\text { central aspect of the work. }\end{array}$ & Yes & Yes \\
\hline $\begin{array}{l}\text { Plan and work } \\
\text { in } \\
\text { collaboration } \\
\text { with teachers. }\end{array}$ & $\begin{array}{l}\text { 6. The goal of the project was to develop } \\
\text { teachers' use of digital tools. }\end{array}$ & $\begin{array}{l}\text { Five activities were planned } \\
\text { together with teachers who } \\
\text { thereafter applied their skills } \\
\text { tothe pupils. }\end{array}$ & Yes & No \\
\hline $\begin{array}{l}\text { Plan and work } \\
\text { in } \\
\text { collaboration } \\
\text { with teachers } \\
\text { and pupils. }\end{array}$ & $\begin{array}{l}\text { 7. The goal of the procedures was to find } \\
\text { opportunities for working with digital } \\
\text { tools despite scarce ICT-resources in the } \\
\text { leisure-time center. }\end{array}$ & $\begin{array}{l}\text { With a minimum of digital } \\
\text { resources, a computer, a } \\
\text { projector and an iPad, a } \\
\text { number of varying activities } \\
\text { were carried out in a leisure- } \\
\text { time center with ca. } 40 \text { pupils. }\end{array}$ & Yes & Yes \\
\hline
\end{tabular}


International Journal of Computer Science \& Information Technology (IJCSIT) Vol 11, No 3, June 2019

\begin{tabular}{|c|c|c|c|c|}
\hline \multirow[t]{6}{*}{$\begin{array}{l}\text { Plan and work } \\
\text { in } \\
\text { collaboration } \\
\text { with teachers } \\
\text { and children } \\
\text { where digital } \\
\text { resources are } \\
\text { used in a non- } \\
\text { ICT-related } \\
\text { problem. }\end{array}$} & $\begin{array}{l}\text { 8. The goal is to develop ICT-skills, with } \\
\text { the emphasis placed on wanting to } \\
\text { increase pupils' physical activity. }\end{array}$ & $\begin{array}{l}\text { By using software and } \\
\text { applications that inspire } \\
\text { exercise and physical activity. }\end{array}$ & Yes & Yes \\
\hline & $\begin{array}{l}\text { 9. The goal is to develop ICT-skills, with } \\
\text { the emphasis placed on wanting to } \\
\text { increase children's physical activity. }\end{array}$ & $\begin{array}{l}\text { By using software and } \\
\text { applications that inspire } \\
\text { exercise and physical activity. }\end{array}$ & Yes & Yes \\
\hline & $\begin{array}{l}\text { 10. The goal is to develop ICT-skills, } \\
\text { with the emphasis placed on wanting to } \\
\text { increase children's physical activity. }\end{array}$ & $\begin{array}{l}\text { By using software and } \\
\text { applications that inspire } \\
\text { exercise and physical activity. }\end{array}$ & Yes & Yes \\
\hline & $\begin{array}{l}\text { 11. The goal is to develop ICT-skills, } \\
\text { with the emphasis placed on increasing } \\
\text { the pupils' participation. }\end{array}$ & $\begin{array}{l}\text { Through publishing a podcast } \\
\text { with the pupils' own story. }\end{array}$ & Yes & Yes \\
\hline & $\begin{array}{l}\text { 12. The goal is to develop ICT-skills, } \\
\text { with the emphasis placed on increasing } \\
\text { the pupils' participation. }\end{array}$ & $\begin{array}{l}\text { Through publishing a podcast } \\
\text { with the pupils' own story. }\end{array}$ & Yes & Yes \\
\hline & $\begin{array}{l}\text { 13. The goal is to develop ICT-skills, } \\
\text { withthe emphasis placed on increasing } \\
\text { the parents' possibility to oversee and } \\
\text { influence. }\end{array}$ & $\begin{array}{l}\text { Through using Instagram in } \\
\text { video format, with } \\
\text { accompanying description and } \\
\text { captions. }\end{array}$ & Yes & Yes \\
\hline
\end{tabular}

Of the 13 development projects that have been studied, there are several students who chose the same goal, project design and method. There are six development projects that have clearly placed the use of digital tools in the forefront. Three projects have primarily worked with physical activities, and two development projects have placed the pupils' increased influence as central. Thus, five projects have put the digital use more in the background. A summary review of the projects shows that those that carried out a careful current state analysis and needs analysis, make a greater impact in the subsequent interventions. The fact that teachers are key persons in the work, appears in all the documentation. The results of the conducted current state analyses show that there are varying shortcomings in both the teachers' and pupils' digital skills. The motivation to learn is high independent of the ability level, and it increases when the beneficial effect becomes apparent. All development projects show the importance of having technology that works, and if a technical problem arises, computer support should be available.

\section{CONCLUSIONS AND IMPLICATIONS}

An earlier survey has shown that thesis projects with a development-oriented approach do very well achieving scientific quality [29]. The projects included in this study have encountered the scientific requirements for implementation and documentation in all respects. The manner of gaining the success greatly depend mainly on how well the development intervention is based on the practicum-school. Important conditions are good cooperation between teachers and studentteachers and that the student has a significant independent role in the common interest in developing the leisure-time center. The student-teachers provide important extra resources in terms of planning, implementation and documentation, which are of great importance for a successful competence development intervention. If one can build upon an earlier project, then that is even better.

Integrating all participants in social learning happens to be a success factor for development projects with an ICT-focus. The projects that have clear objectives for cooperation and collegial 
learning are considered to have achieved more in goal attainment than those projects that were more oriented toward individual instruction. When one only focuses on pupils in a project, there is a big risk that one further builds a digital distance to the teachers, who then in such a design, miss out on their own competence development.

When the work with digital tools is rooted in another subject area, for example, physical activity or values issues, the competence development appears to have become even more efficient. There are many possible reasons for this. In reference to the four reasons that can explain a lack of success in ICT-oriented in-service training [21] there is no particularly indicated time for training. The teacher works with digital tools in an area where they should be working during ordinary scheduled time. When there is time for collegial collaboration and one sees a concrete change, no one questions the benefits of the intervention. Another reason concerns the teacher not encountering an uncomfortable comparison with the pupil in terms of knowledge and skills. If teachers are part of instruction with a traditional teaching design and discover that some pupils have a competence advantage, some teachers can experience this as challenging and shameful. When the project places another problem in the foreground, usually something that the teacher has more insight into, the use of the digital tools moves into the background. As a teacher, one has two competence areas to work with, and if the teacher is weaker in one area, he or she can compensate for that with other skills. The barriers defined as psychological, value and power, do not occur when the digital equipment is not the focus, but is used as a legitimate tool for obtaining other goals.

In a society characterized by rapid and significant changes, the school is going to face major new challenges. Teachers must therefore master the skills and experience of development and change work. A development-oriented thesis project is very conducive to this educational challenge. This type of work also seems to strengthen independence and responsibility in preparation for one's future professional practice, which is considered important by researchers [34, 35, 36 ]

Not all schools have the same conditions for working with development-oriented thesis projects. At several of the schools there was a lack of sufficient digital resources, and many schools lack student-teachers. It must be a goal to reduce these differences. Material resources can be prioritized and bridged, but recruiting and engaging student-teachers is more complicated when teacher education is limited and concentrated to cities. Increasing the digital skills of teachers and students is an important development area, and this type of action-oriented thesis project may be an effective means in this endeavour. One idea for increasing the number of projects with this focus may be to let the students reformulate their traditional problem formulations for development-oriented purposes and goals. This can provide valuable experience and positive impact in school classrooms.

\section{REFERENCES}

[1] Riis, U. (2000). IT iskolanmellan vision ochpraktik: enforskningsöversikt [IT in school between vision and practice: A research overview]. Stockholm: Skolverket.

[2] Karlsohn, T. (2009). Teknik - retorik - kritik: om IT-bubblanochdatoriseringenav den svenskaskolan [Technology - rhetoric - criticism: The IT-bubble and the digitalization of the Swedish school]. Stockholm: Carlsson.

[3] Karlsson, L. (2015). Framgångsfaktorer i PIM - Praktisk IT- och mediekompetens. En enkät- och intervjustudie av Myndigheten för skolutvecklings- och Skolverkets fortbildningssatsning på ITkompetens för Sveriges pedagoger 2006 - 2014 [Successfactors in PIM - Practical IT - and mediaskills. A survey and interview study by the Authority for School Development and the Swedish National Agency for Education, In-service training of IT-skills for Swedish educators 2006-2014]. 
International Journal of Computer Science \& Information Technology (IJCSIT) Vol 11, No 3, June 2019

Magisteruppsats, Institutionen för Didaktik och Pedagogisk Profession. Göteborg: Göteborgs universitet.

[4] Ahlbäck, T. (2018). Digitala skrivtavlor - till vad, hur och varför?: En studie om den digitala skrivtavlans betydelse för grundskolans digitalisering utifrån ett lärarperspektiv [Digital writing tablets - what, how and why?: A study on the digital writing tabletimportance for elementaryschooldigitalizationbased on a teacherperspective]. Doctoral Thesis. Växjö, Linnaeus University Press. 195.

[5] Karlsudd, P. (2015). ICT and Learning in School. Journal of Emerging Trends in Computing and Information Sciences, 6(12), 677-684.

[6] Wastiau, P., Blamire, R., Kearney, C., Quittre, V., Van de Gaer, E. \&Monseur, C. (2013) The use of ICT in education: A survey of schools in Europe. European Journal of Education 48(1), 11-27.

[7] Bebell, D., O’Dwyer, L.M., Russell, M. \& Hoffmann, T. (2010). Concerns, Considerations, and New Ideas for Data Collection and Research in Educational Technology Studies. Journal of Research on Technology in Education, 43(1), 29-52.

[8] Olofsson, A.D., Lindberg, O.J., Fransson, G. \& Haugh, T.E. (2011). Uptake and Use of Digital Technologies in Primary and Secondary Schools: a Thematic Review of Research. Nordic Journal of Digital Literacy, 6(4), 207-225.

[9] Aldunate, R. \& Nussbaum, M. (2013). Teacher adoption of technology. Computers in Human Behavior, 29(3), 519-524.

[10] Karlsudd, P. (2010). For benefit or oblivion?: From idea and vision to the implementation and support of Learning Applications. International Journal of Advanced Research in Computer Science. 1. 7989.

[11] Sandberg, V. \&Karlsudd, P. (2014). Learning by playing: Searching after a connection between computer games. Journal of Emerging Trends in Computing and Information Sciences. 5. 371-376.

[12] Vetenskapsrådet, 2017 Forskningsetiskaprinciperinomhumanistisk-samhällsvetenskapligforskning [Principles of research ethics in Humanities and Social Sciences research]. Stockholm: Vetenskapsrådet.

[13] Malmsten, L. \& Hedlund, S. (2013). IKT på fritidshemmet - ett socialt och kulturellt fenomen [ICT in the leisure-time center - a social and culturalphenomenon]. Skolportens numrerade artikelserie för utvecklingsarbete i skolan. Artikelnummer 2/2013.

[14] SOU (2015: 28) Gör Sverige i framtiden - digital kompetens [Make Sweden for the future - digital skills]. Delbetänkande av Digitaliseringskommissionen. Stockholm:

[15] Hylén, J. (2013). Digitalisering i skolan [Elektronisk resurs]: en kunskapsöversikt [Digitalization in schools [Electronic resource]: A knowledgeoverview]. Stockholm: Ifous.

[16] Oxstrand, B. (2013). Från media literacy till mediekunnighet: lärares uppfattning och förståelse av begreppen mediekunnighet och IKT i skolan och deras syn på medieundervisning [From media literacy to media proficiency: Teachers' perceptions and understandingof the conceptof media proficiency and ICT in school and theirviewof media instruction]. LicentiatavhandlingGöteborg: Göteborgsuniversitet.

[17] Håkansson Lindqvist, M. (2015). Conditions for technology enhanced learning and educational change: a case study of a 1:1 initiative. Diss. Umeå: Umeå University. 
[18] Klerfelt, A. (2007). Barns multimedialaberättande: enlänkmellanmediakulturochpedagogiskpraktik [Children's multimedia storytelling: A link between media culture and pedagogical practice]. Diss. (sammanfattning) Göteborg: Göteborgs universitet, 2007. Göteborg.

[19] Karlsudd, P., Tågerud, Y. (2008). Bridging the Gap - Taking the Distance out of e-Learning. EJEL Electronic Journal of e-Learning. 6. 43-53

[20] Perselli, A.K. (2014). Fråndatasal till en-till-en: Enstudieavlärareserfarenheteravdigitalaresurseriundervisningen [From computer room to one-on-one: A study of teachers' experiences of digital resources in instruction]. Härnösand: Mittuniversitetet

[21] Willermark, S. (2018). Digital didaktisk design: Att utveckla undervisning i och för en digitaliserad skola [Digital didactic design: Developing instruction in and for a digitalizedschool]. Diss. (sammanfattning). 2018. Trollhättan: Högskolan Väst.

[22] Blomgren, J. (2016). Den svårfångade motivationen: elever i en digitaliserad lärmiljö [Hard-tocapture motivation: pupils in a digitalizedlearningenvironment]. Diss. Göteborg: Göteborgsuniversitet (2016).

[23] AngéliiGenlott, A. \&Grönlund, Å. (2016). Closing the gaps - Improving literacy and mathematics by ICT-enhanced collaboration. Computers \& Education, 99, 68-80.

[24] Penuel, W.R. (2006). Implementation and effects of one-to-one computing initiatives: A research synthesis. Journal of Research on Technology in Education, 38(3), 329-348.

[25] Lindstrand, P. \&Brodin, J. (2006) ICT somenintegrerandelänkför barn ochunga med rörelsehinder [ICT as an integrating link for children and youths with physical disabilities]. Rapport nr 45, Teknik, Kommunikation \& Handikapp. Stockholm: Lärarhögskolan i Stockholm.

[26] Samuelsson, U. (2014). Digital (o)jämlikhet?: IKT-användning i skolan och elevers tekniska kapital [Digital (in)equality?: ICT-use in school and pupils' technologycapital]. Diss. Jönköping: Högskolan i Jönköping.

[27] Ottenbreit-Leftwich, A T., Glazewski, K. D., Newby, T. J., \&Ertmer, P. A. (2010). Teacher value beliefs associated with using technology: Addressing professional and student needs. Computers and Education, 55 (3), 1321-1335.

[28] Karlsudd, P. (2018b). Cheating or legitimate support?: Student-Teachers' attitudes toward digital tools in school. Support for Learning. 33. 338-359.

[29] Karlsudd, P., Dahl, M., Willén-Lundgren, B. (2017). Less tradition for more profession: an attempt with thesis projects in practical development. Problems of Education in the 21st Century. 75. 252262.

[30] Högskoleverket. (2005). Utvärdering av den nya lärarutbildningen vid svenska universitet och högskolor, Del 1 [Evaluationof the new teachereducation program in Swedish universitiesand colleges, Part I]. Högskoleverketsrapportserie 2005:17R. Stockholm: Högskoleverket.

[31] Reis-Jorge, J. (2007). Teacher's conceptions of teacher-research and self-perceptions as enquiring practitioner: A longitudal case study. Teaching and Teacher Education, 23 (4), 402-417.

[32] Gustafsson, C. (2008). Degree projects in higher education. In I. Mattsson, I Johansson \& B. Sandström (Eds.), Examining praxis assessment and knowledge construction in teacher education 1734). Rotterdam: Sense.

[33] Råde, A. (2014). Ett examensarbete för både yrke och akademi: en utmaning för lärarutbildningen [A thesisproject for both profession and academia: A challenge for teachereducation]. Högre utbildning, 4 (1), 19-34. 
[34] Casson, A. (2015). Högskolans ansvar: Principer för utveckling av den högre utbildningen [University responsibility: Principles for developmentofhighereducation]. London: Ubiquity Press.

[35] Dyste, O. (2002). Professors as mediators of academic text cultures: An interview study with advisors and master degree students in three disciplines in a Norwegian university. Written Communication, 19 (4), 493-544.

[36] Sköld, B. (2016). Samverkan och utbildningskvalitet [Cooperation and educationquality]. HELIX årsrapport 16:001. Linköping: Linköpings universitet.

[37] Maslow, A.H. (1954). Motivation and Personality. New York: Harper \& Brothers.

[38] Piaget, J. (1959). The language and thought of the child. London: Routledge.

[39] Utbildnings departementet. (2017a). Nationell digitaliseringsstrategi för skolväsendet [National digitalizationstrategy for the education system]. Dnr U2017/04119/S. Stockholm: NorstedtsJuridik $\mathrm{AB}$.

\section{AUTHORS}

Professor Peter Karlsudds (1958) research interests are centered on the fields of special needs education, flexible learning and teaching and learning in higher education. He took his doctorate in education at Lund University in 1999 with the thesis entitled 'Children with intellectual disability in the integrated school-age care system'. He finished his doctoral thesis in informatics, 'Support for learning? Possibilities and obstacles in learning applications, 2011. This thesis describes in a number of articles work with webbased learning applications and the difficulties of successfully implementing such

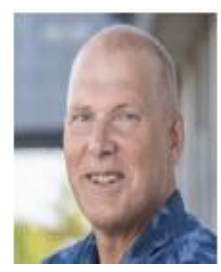
applications and projects in organizations. 